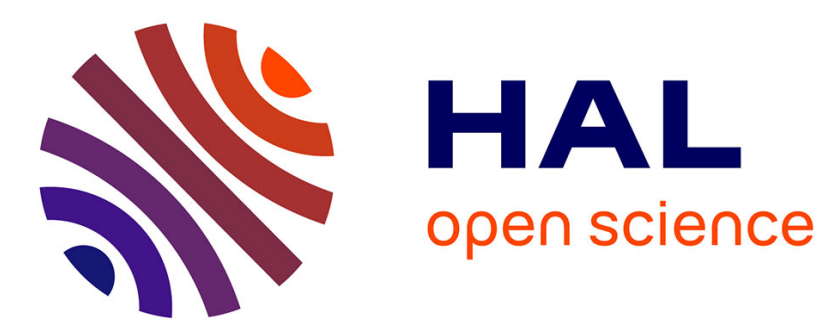

\title{
Transient liquid phase bonding of titanium to aluminium nitride
}

Olivier Dezellus, J. Andrieux, F. Bosselet, M. Sacerdote-Peronnet, T. Baffie, F. Hodaj, N. Eustathopoulos, J.C. Viala

\section{- To cite this version:}

Olivier Dezellus, J. Andrieux, F. Bosselet, M. Sacerdote-Peronnet, T. Baffie, et al.. Transient liquid phase bonding of titanium to aluminium nitride. Materials Science and Engineering: A, 2008, 495 (1-2), pp.254-258. 10.1016/j.msea.2007.10.104 . hal-00322171

\section{HAL Id: hal-00322171 \\ https://hal.science/hal-00322171}

Submitted on 16 Sep 2008

HAL is a multi-disciplinary open access archive for the deposit and dissemination of scientific research documents, whether they are published or not. The documents may come from teaching and research institutions in France or abroad, or from public or private research centers.
L'archive ouverte pluridisciplinaire HAL, est destinée au dépôt et à la diffusion de documents scientifiques de niveau recherche, publiés ou non, émanant des établissements d'enseignement et de recherche français ou étrangers, des laboratoires publics ou privés. 


\title{
Transient liquid phase bonding of titanium to aluminium nitride
}

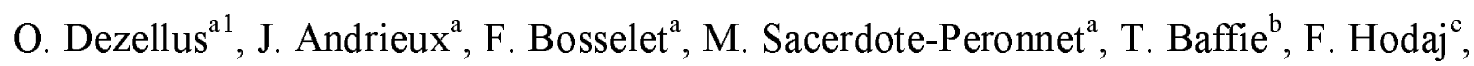
N. Eustathopoulos ${ }^{\mathrm{c}}$, J.C. Viala ${ }^{\mathrm{a}}$

${ }^{a}$ LMI, Université Lyon 1, CNRS, 43 Bd du 11 novembre 1918, 69622 Villeurbanne Cedex, France

${ }^{\mathrm{b}}$ CEA Grenoble, LITEN/DTH/LTH, 17 rue des martyrs, 38054 Grenoble Cedex 9, France

' SIMAP, ENSEEG, CNRS, 1130 rue de la piscine, 38420 Saint Martin d'Hères Cedex, France

\begin{abstract}
Titanium has been successfully joined to aluminium nitride AlN at a temperature as low as $795^{\circ} \mathrm{C}$, using $\mathrm{Ag}-\mathrm{Cu} \mathrm{Cusil} @$ commercial braze alloy. While reactive wetting and spreading proceeds at the AlN/ braze alloy interface, chemical interactions develop at the titanium side rendering possible isothermal solidification of the joint. The determining factor in the solidification process is the fast formation of $\mathrm{TiCu}_{4}$ crystals by heterogeneous nucleation and growth in the liquid phase. As a consequence, the braze alloy is depleted in $\mathrm{Cu}$ and solid Ag precipitates. After annealing, the re-melting temperature of the resulting joint can be increased up to about $910^{\circ} \mathrm{C}$ which is nearly $130^{\circ} \mathrm{C}$ higher than the melting point of the starting braze alloy.
\end{abstract}

Keywords: Transient liquid phase bonding, isothermal solidification, metal to ceramic brazing, Ag-Cu alloy, experimental study, interfacial reactivity

\footnotetext{
${ }^{1}$ Corresponding author: olivier.dezellus@univ-lyonl.fr

Tel: (+33) 472448386 / Fax: (+33) 472440618
} 


\section{Introduction}

Joining together titanium or titanium base alloys to ceramics (such as $\mathrm{Al}_{2} \mathrm{O}_{3}, \mathrm{Si}_{3} \mathrm{~N}_{4}, \mathrm{SiC}$, $\left.\mathrm{Ti}_{3} \mathrm{SiC}_{2} \ldots\right)$ are important issues to be addressed in the scope of producing low-weight high-strength components such as heat exchangers parts or turbine blades for use at medium temperature. A way of great potential for achieving these goals consists in joining the base metal to the ceramics by brazing with a filler alloy $[1,2]$. The present work is focussed on the chemical-physical aspect of joining pure titanium to sintered AlN with silver-based braze alloys. Such alloys have been chosen since pure liquid silver has already been used to join titanium alloys [3]. Moreover, the Ag-Ti compounds $\mathrm{Ag}_{2} \mathrm{Ti}$ and $\mathrm{AgTi}$ are not very stable: they decompose at 930 and $1030^{\circ} \mathrm{C}$, respectively [4]. Therefore, a high titanium activity in the liquid favourable to fast reactive wetting of AlN can be expected. On the other hand, the mismatch in coefficient of thermal expansion (CTE) between Ti and AIN can induce the development of residual stresses, cracking of the ceramic and failure of the assembly. Lowering the brazing temperature is key to limiting the effect of CTE mismatch, but it also implies a decrease of the working temperature for the brazed assembly that should be high enough for good wetting and spreading [2]. Transient liquid phase bonding (TLPB), i.e. isothermal solidification of the braze alloy, is a promising method to satisfy both of these contradictory requirements [5-9].

Therefore, four alloying elements that form a homogeneous liquid with $\mathrm{Ag}$ at temperatures lower than the melting point of pure Ag have been tested: these are $\mathrm{Si}, \mathrm{Ge}$, $\mathrm{Sn}$ and $\mathrm{Cu}$. Among them, $\mathrm{Cu}$ has given the best results in terms of successful brazing accompanied by isothermal solidification 


\section{Materials and experimental procedure}

When available, the starting materials used in the present work were commercial products. Pure titanium T40 or grade 2 (pure Ti with, in wt. $\%: \mathrm{O}<0.25 ; \mathrm{Fe}<0.30$; $\mathrm{H}<0.015 ; \mathrm{C}<0.10 ; \mathrm{N}<0.03$ ) was supplied by Ninatec in the form of laser cut small plates with a thickness of $1 \mathrm{~mm}$. Sintered AIN ceramics were supplied by Boostec in the form of plates with a thickness of $0.5 \mathrm{~mm}$. The plates had a surface roughness of the order of $0.5 \mu \mathrm{m}$ and their residual porosity was of 2 vol. $\%$. They contained $3-5 \mathrm{wt} . \%$ of yttria $\left(\mathrm{Y}_{2} \mathrm{O}_{3}\right)$ and oxygen was present at their surface down to a depth of a few tenths of nanometers [10]. No surface treatment other than degreasing and rinsing was applied to AlN whereas the surface of titanium was deoxidized by mechanical grinding just before brazing. The Ag-Cu brazing alloy was supplied by Goodfellow in the form of $50 \mu \mathrm{m}$ thick sheets. The copper content of 28 wt.\% (40 at.\%Cu) corresponds to the $\mathrm{Ag}-\mathrm{Cu}$ eutectic composition with a melting point at $780^{\circ} \mathrm{C}$.

To evaluate wetting on and spreading of the braze alloy onto AIN and Ti, some sessile drop experiments were carried out under vacuum $\left(10^{-5} \mathrm{~Pa}\right)$ in an experimental apparatus comprising an alumina tube heated by a $\mathrm{SiC}$ resistor that was already described elsewhere [11]. Brazing experiments were realized in a hot wall horizontal quartz tube that was placed in a conventional tubular furnace. The experiments were carried out under vacuum $\left(10^{-1} \mathrm{~Pa}\right)$ with $\mathrm{Ti}$ powder as gas getter to reduce the residual oxygen partial pressure. The plateau temperature was regulated to better than $\pm 3 \mathrm{~K}$, the heating and cooling rates were also controlled. In the following, all the reported brazing times correspond to the effective period for which the sample has been maintained at constant temperature, transient heating and cooling times excluded. When necessary, crucibles 
were lined with $\mathrm{Y}_{2} \mathrm{O}_{3}$ (STOPYT 62A, Morgan Wesgo) to insure confinement of the liquid braze alloy.

After heat treatment and cooling to room temperature, the samples were characterized by optical metallography (OM), scanning electron microscopy (SEM) and electron probe microanalysis (EPMA). In parallel to the study on interfaces, a phase characterization was carried out by X-ray diffraction ( $\mathrm{XRD}, \mathrm{Cu} \mathrm{K} \alpha$ radiation) and EPMA on Ag-Cu-Ti cold-pressed powder samples heat-treated at the same temperature and for the same time [12]. It was thus verified that the crystalline phases for which the interface reaction layers or particles analysed were effectively obtained under these conditions.

\section{Results and discussion}

\section{1. Joining AlN to Ti with Ag at $970-980^{\circ} \mathrm{C}$}

In a first step, it was verified that the AlN ceramics used in this work (with its surface oxide layer) was wetted by a liquid Ag-Ti alloy prepared in-situ by direct melting of Ag and $\mathrm{Ti}$ on the AlN substrate (sessile drop configuration). An experiment made at $970^{\circ} \mathrm{C}$ effectively showed good wetting of a small AlN plate by liquid silver with 0.5 at.\% of $\mathrm{Ti}$ added. After an induction period of $300 \mathrm{~s}$, corresponding to the dissolution of solid $\mathrm{Ti}$ in liquid $\mathrm{Ag}$, an equilibrium contact angle of $30^{\circ}$ was attained in $600 \mathrm{~s}$. When more than 0.5 at. $\% \mathrm{Ti}$ was present in liquid $\mathrm{Ag}$, a smaller contact angle $\left(20^{\circ}\right)$ was attained in a shorter time (300 s). Depending on the Ti activity, spreading of the liquid alloy was associated with the formation at the triple line of either a single thin layer of nitrogenpoor titanium nitride $\left(\mathrm{TiN}_{1-\mathrm{x}}\right)$ onto AlN (low Ti activity) or a double reaction layer with 
$\mathrm{TiN}_{1-\mathrm{x}}$ on the $\mathrm{AlN}$ side and a complex compound ( $\left.\mathrm{Ti}, \mathrm{Ag}, \mathrm{Al}\right)_{6} \mathrm{~N}$ on the liquid side (high Ti activity).

Reactive wetting with the formation of $\mathrm{TiN}_{0.43}$ at the AlN/liquid interface was also observed when T40 was brazed to AlN at $977^{\circ} \mathrm{C}$ for 15 min using a $100 \mu \mathrm{m}$ thick sheet of pure $\mathrm{Ag}$ as filler metal. Spreading of liquid $\mathrm{Ag}$ on solid $\mathrm{Ti}$, dissolution of the latter element at the Ti/liquid interface and migration of $\mathrm{Ti}$ in the liquid towards the $\mathrm{AlN}$ surface thus appeared as fast processes. Moreover, once a chemical bond was established at the interface between AIN and the Ag-rich liquid, the latter reacted at $977^{\circ} \mathrm{C}$ with Ti to give solid AgTi (AgTi m.p. $=1020^{\circ} \mathrm{C}$ ). Quick thickening of the AgTi layer demonstrated the feasibility of joining AlN to Ti with Ag by transient liquid phase bonding with a reasonable time-temperature cycle. Therefore having arrived at this point, the matter was to lower the brazing temperature by adding an element to $\mathrm{Ag}$ to decrease its melting point.

\section{2. Evaluation of binary $\mathrm{Ag}-\mathrm{Cu}$ braze alloys at $850^{\circ} \mathrm{C}$}

Further brazing experiments were carried out at $850^{\circ} \mathrm{C}$ for 40 min with the $\mathrm{Ag}-\mathrm{Cu}$ braze alloy. As expected from previous work, $[13,14]$ clean Ti surfaces were easily wetted by the liquid alloy that appeared entirely solidified in the form of pure Ag after $40 \mathrm{~min}$ brazing. It is worth noting that a continuous $\mathrm{Ti}_{\mathrm{x}} \mathrm{Cu}_{\mathrm{y}}$ reaction layer with a thickness of 15-25 $\mu \mathrm{m}$ was formed at the $\mathrm{Ti} /$ alloy interface, replacing the thick AgTi compound layer previously characterized at $977^{\circ} \mathrm{C}$ when pure $\mathrm{Ag}$ was used. Good reactive wetting and chemical bonding was also observed at the AlN surface with the formation of a double layer $\operatorname{TiN}_{1-\mathrm{x}}+(\mathrm{Ti}, \mathrm{Ag}, \mathrm{Cu}, \mathrm{Al})_{6} \mathrm{~N}$. These results are in agreement with previous observations made at AlN/Ag-Ti-Cu interfaces [15-17]. 
Formation of $\mathrm{TiN}_{1-\mathrm{x}}$ at the AlN/braze alloy interface according to the chemical equation below promotes spreading of the braze alloy on the AlN substrate by reactive wetting: [18]

$$
\mathrm{Ti}_{\text {diss }}+\mathrm{AlN} \rightarrow \mathrm{TiN}+\mathrm{Al}_{\text {diss }}
$$

In this reaction, $\mathrm{AlN}$ and $\mathrm{TiN}_{1-\mathrm{x}}$ are in the solid state whereas $\mathrm{Ti}$ and $\mathrm{Al}$ are dissolved in the liquid braze alloy. At $850^{\circ} \mathrm{C}$, the Gibbs free energy variation for this reaction is not very negative, of the order of $-33 \mathrm{~kJ} \cdot \mathrm{mol}^{-1}$ [19]. Accordingly, the reaction can proceed only if the chemical activity of Ti in the liquid braze alloy is high enough (higher than 3 $10^{-3}$ with reference to liquid state). That condition is fulfilled when the braze alloy is either pure $\mathrm{Ag}$ or an $\mathrm{Ag}-\mathrm{M}$ alloy that does not form very stable $\mathrm{Ti}_{\mathrm{X}} \mathrm{M}_{\mathrm{y}}$ compounds at the Ti/liquid interface (case of $\mathrm{Cu}$ ). For other alloying elements that form more stable compounds with titanium such as $\mathrm{Si}, \mathrm{Ge}$ and $\mathrm{Sn}$, the activity of $\mathrm{Ti}$ in the liquid braze alloy is too low to convert $\mathrm{AlN}$ into $\mathrm{TiN}_{1-\mathrm{x}}$, as experimentally verified after $40 \mathrm{~min}$ brazing at $850^{\circ} \mathrm{C}$. A more quantitative approach consists in comparing the enthalpies of formation of Ti-M bonds using the Miedema's model [20]. From the results presented in Table 1, it is clear that $\mathrm{Ag}$ and $\mathrm{Cu}$ form the weakest bonds with $\mathrm{Ti}$. It is then in pure $\mathrm{Ag}$ and in the Ag-Cu alloys that the activity of $\mathrm{Ti}$ is the highest, which justifies the use as braze alloy of eutectic $\mathrm{Ag}-\mathrm{Cu}$ with 40 at. $\% \mathrm{Cu}\left(28\right.$ wt. $\left.\% \mathrm{Cu}, \mathrm{m} . \mathrm{p} .=780^{\circ} \mathrm{C}\right)$.

\begin{tabular}{lcccc}
\hline $\mathrm{M}$ & $\Delta \mathrm{H}^{\text {for }}(\mathrm{kJ} / \mathrm{mol}$ of atoms $)$ & & \\
\hline & $\mathrm{TiM}_{2}$ & $\mathrm{TiM}$ & $\mathrm{Ti}_{2} \mathrm{M}$ & $\mathrm{Ti}_{5} \mathrm{M}$ \\
$\mathrm{Ag}$ & -17 & -21 & -18 & -10 \\
$\mathrm{Cu}$ & -24 & -27 & -21 & -11 \\
$\mathrm{Sn}$ & -46 & -62 & -58 & -32 \\
$\mathrm{Ge}$ & -54 & -74 & -64 & -33 \\
$\mathrm{Si}$ & -61 & -82 & -69 & -35 \\
\hline
\end{tabular}

Table 1. Calculated values for the heat of formation, $\Delta \mathrm{H}^{\text {for }}$ of Ti-M compounds of four different compositions according to the Miedema's model [20]. 


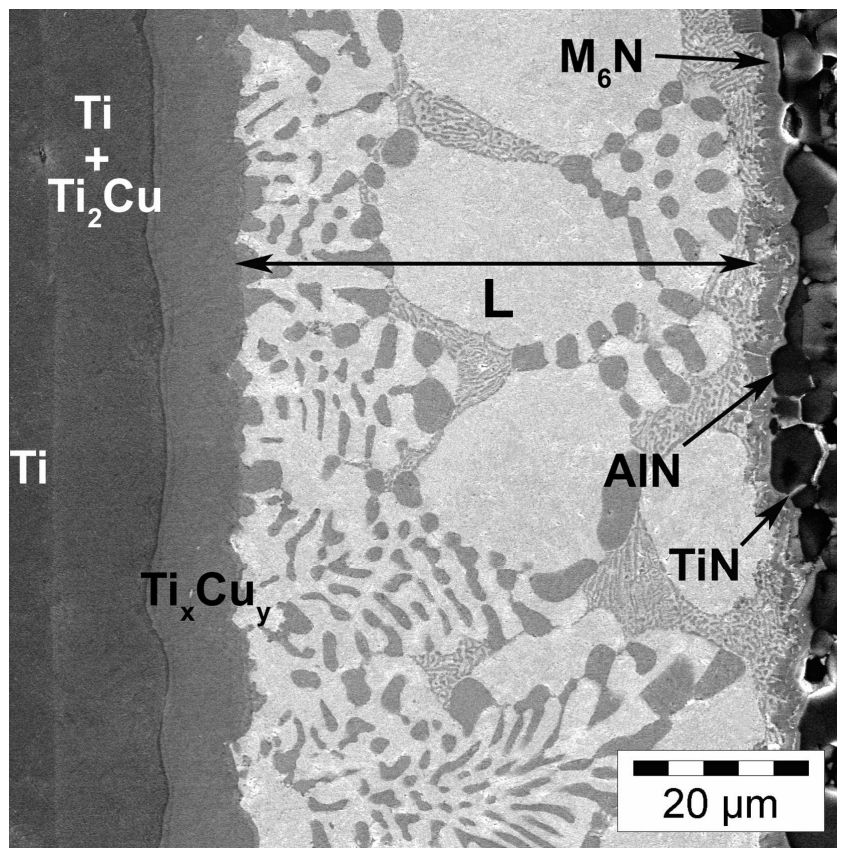

Fig. 1. SEM image of a Ti/ $\mathrm{Ag}-\mathrm{Cu} 40 \mathrm{at} \% / \mathrm{AlN}$ joint brazed for $8 \mathrm{~min}$ at $850^{\circ} \mathrm{C}$ : reactive wetting at both interfaces; the braze alloy has enriched in Ag but its crystallization occurred upon cooling (Ag-Cu eutectic between primary Ag grains)

Fig. 1 shows a Ti/ Ag-Cu40at\%/ AlN joint after brazing for $8 \mathrm{~min}$ at $850^{\circ} \mathrm{C}$. It is clear that at the end of the brazing operation, most of the braze alloy is still in the liquid state. Indeed, the microstructure of this alloy exhibits in many places the characteristic morphology of a solidified Ag-Cu eutectic alloy with dark round-shaped crystals of $\mathrm{Cu}$ embedded in a white Ag matrix. Large primary Ag grains can however be seen which indicates an enrichment in $\mathrm{Ag}$ of the alloy during brazing. Some $\mathrm{Al}$ from $\mathrm{AlN}$ has also dissolved in the liquid alloy. Upon cooling, $\mathrm{Al}$ precipitated with $\mathrm{Cu}$ and $\mathrm{Ti}$ in the form of the fine grey particles visible between the primary $\mathrm{Ag}$ grains near the AlN surface. On the Ti side, a continuous reaction zone with a thickness of $10-20 \mu \mathrm{m}$ is observable. According to EPMA analyses, the reaction layer sequence in this zone is $\mathrm{Ti} / \mathrm{Ti}+\mathrm{Ti}_{2} \mathrm{Cu}$ / 
$\mathrm{Ti}_{2} \mathrm{Cu} / \mathrm{TiCu} / \mathrm{Ti}_{3} \mathrm{Cu}_{4} / \mathrm{Ti}_{2} \mathrm{Cu}_{3} / \mathrm{L}$. On the AlN side, the ceramic surface is coated with a thin (less than $1 \mu \mathrm{m}$ thick) and continuous layer of $\mathrm{TiN}_{1-\mathrm{x}}$, itself covered with a layer of grey particles containing $\mathrm{Ti}, \mathrm{N}, \mathrm{Al}$ and $\mathrm{Cu}$ mixed with metallic silver. The reaction zone on the AlN side is the same as that characterized by Carim and Loehman [17] with two sublayers: a layer of $\mathrm{TiN}_{0.67}$ on $\mathrm{AlN}$ and another sublayer mainly consisting of a quaternary phase $(\mathrm{Ti}, \mathrm{Cu}, \mathrm{Al})_{6} \mathrm{~N}$ whose crystal structure has been determined by Durlu et al. [21].

\section{3. Brazing at $795^{\circ} \mathrm{C}$ with an Ag-Cu eutectic alloy}

Fig. 2 shows the typical morphology of a Ti/ $\mathrm{Ag}-\mathrm{Cu} 40$ at.\%/ AlN joint after 8 min brazing at $795^{\circ} \mathrm{C}$, which is $55^{\circ} \mathrm{C}$ lower than previously and only $15^{\circ} \mathrm{C}$ above the melting point of the braze alloy. As in the former case, Ti and AlN have been readily wetted by the liquid Ag-Cu alloy. On the AlN side, a thin (about $0.5 \mu \mathrm{m}$ ) but continuous layer of titanium nitride has developed all over the AlN surface and around some AlN grains located close to the surface (Fig. 2). This means that the liquid braze alloy has not only spread onto AlN surface but has also infiltrated grain boundaries of the sintered ceramic by reactive wetting. On the Ti side, a reaction zone extending over more than a half of the joint width is observable. In this reaction zone, the layer sequence is $\mathrm{Ti} / \mathrm{Ti}_{2} \mathrm{Cu}$ / $\mathrm{TiCu} / \mathrm{Ti}_{3} \mathrm{Cu}_{4}+\mathrm{Ag} / \mathrm{TiCu}_{4}+\mathrm{Ag}$. Compared with what was observed at $850^{\circ} \mathrm{C}$, the twophased sub-layer $\mathrm{Ti}+\mathrm{Ti}_{2} \mathrm{Cu}$ has disappeared at the inner side of the reaction zone and the thin $\mathrm{Ti}_{2} \mathrm{Cu}_{3}$ layer located at its outer side has been replaced by a wide two-phased layer mainly consisting of solid $\mathrm{Ag}$ mixed with crystals of the compound $\mathrm{TiCu}_{4}$. It is worth noting that the volume of the liquid remaining in the joint after 8 min brazing is much smaller at 795 than at $850^{\circ} \mathrm{C}$. In other words, isothermal solidification proceeds faster at $795^{\circ} \mathrm{C}$ than at $850^{\circ} \mathrm{C}$. 


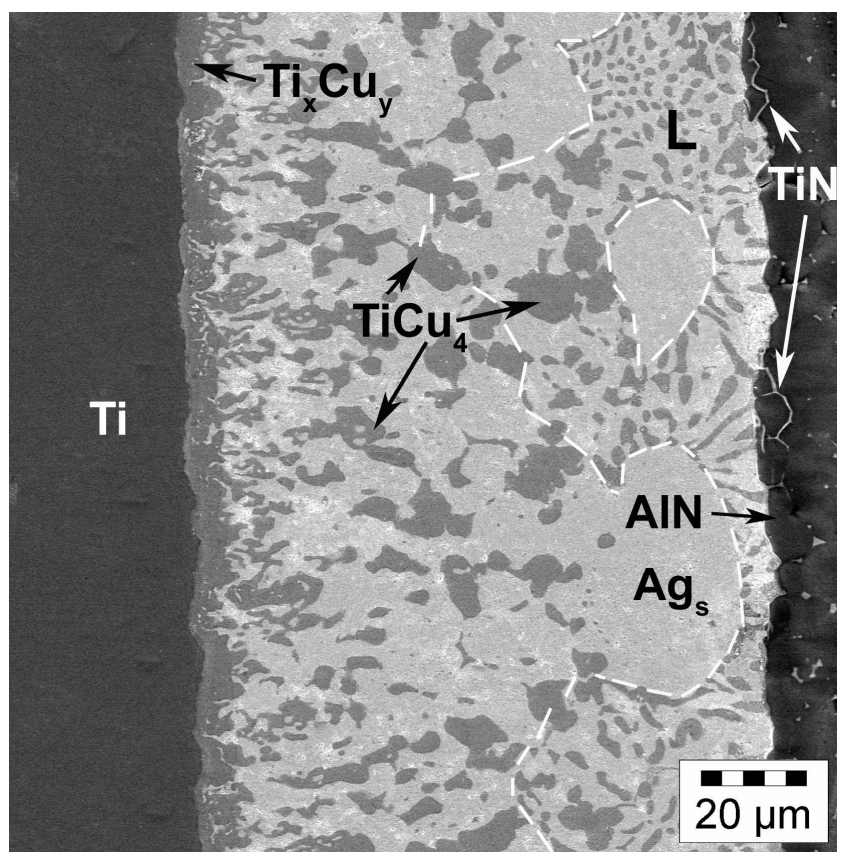

Fig. 2. SEM image of a Ti/ Ag-Cu40at $\% / \mathrm{AlN}$ joint after brazing for $8 \mathrm{~min}$ at $795^{\circ} \mathrm{C}$ : spreading by reactive wetting at both interfaces and isothermal solidification of the braze alloy over more than a half of its volume (the dotted line shows the liquid-solid boundary at $\left.795^{\circ} \mathrm{C}\right)$

\section{4. Low temperature wetting and solidification mechanism}

As soon as the Ag-Cu alloy melts, the Ti base metal begins to dissolve in the liquid. A Ti chemical activity gradient thus appears between the surfaces of the base metal (where the Ti activity is the highest) and AlN (where it is the smallest). When the Ti activity is sufficiently high in the vicinity of the $\mathrm{Ti}$ surface, $\mathrm{TiCu}_{4}$ crystals precipitate. The $\mathrm{Ti}$ activity at the AlN/liquid interface also increases and, after a certain induction period, becomes higher than the threshold value for the formation of $\mathrm{TiN}_{1-\mathrm{x}}$. At this moment, the liquid begins to spread on the ceramics by reactive wetting. Further growth of $\operatorname{TiN}_{1-x}$ and $\mathrm{TiCu}_{4}$ then proceeds by liquid phase diffusion of $\mathrm{Ti}$ and $\mathrm{Cu}$ atoms down the chemical potential gradients of opposite sign that have established in the liquid braze alloy. Growth of $\mathrm{TiCu}_{4}$ crystals is accompanied by the precipitation of solid Ag grains 
from the liquid $\mathrm{Ag}-\mathrm{Cu}$ braze alloy. This gives rise to the formation and growth of a twophased $\mathrm{TiCu}_{4}+\mathrm{Ag}$ solid layer. An important feature shown in Fig. 2 is that large $\mathrm{TiCu}_{4}$ crystals grow at the boundary between the solid $\mathrm{Ag}$ grains and the liquid $\mathrm{Ag}-\mathrm{Cu}$ alloy. This means that if crystallization of $\mathrm{TiCu}_{4}$ and $\mathrm{Ag}$ effectively begins at the $\mathrm{Ti}$ surface where the $\mathrm{Ti}$ activity is the highest, it propagates by heterogeneous liquid-solid nucleation and growth. It is the latter process that results in rapid isothermal solidification of the braze alloy at low temperature.

As long as an $\mathrm{Ag}-\mathrm{Cu}$ liquid is present in the joint, the reaction layer sequence over by the Ti side is: $\mathrm{Ti} / \mathrm{Ti}{ }_{2} \mathrm{Cu} / \mathrm{TiCu} / \mathrm{Ti}_{3} \mathrm{Cu}_{4}+\mathrm{Ag} / \mathrm{TiCu}_{4}+\mathrm{Ag} / \mathrm{L}$. The corresponding diffusion path has been drawn in the Ag-Cu-Ti phase diagram at $795^{\circ} \mathrm{C}$ presented in Fig. 3 (the calculated isotherm is based on) [22]. It can be remarked that the $\mathrm{Ti}_{2} \mathrm{Cu}_{3}$ compound is missing, which can be explained by kinetics considerations [12].

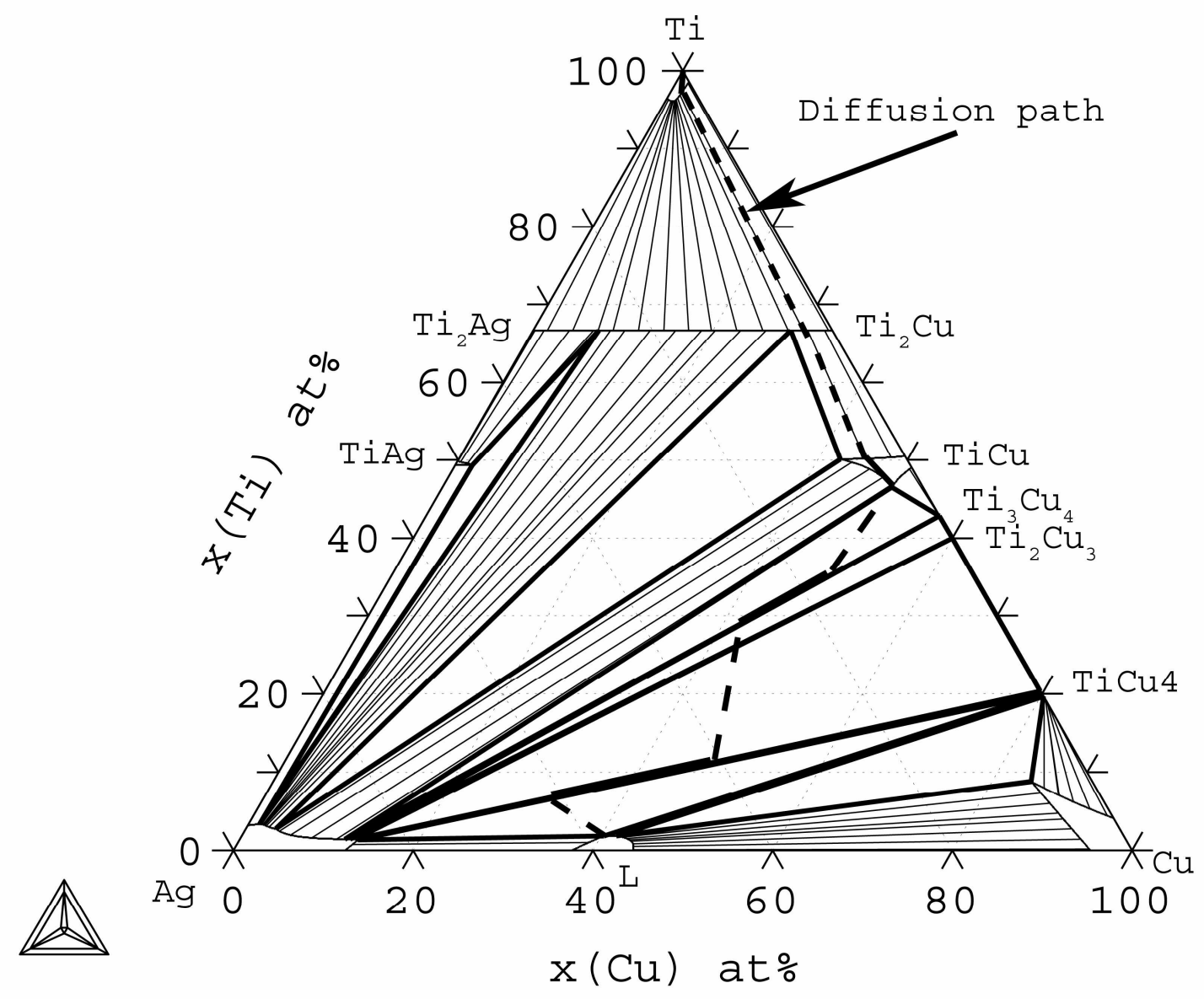


Fig. 3. Ag-Cu-Ti phase diagram at $795^{\circ} \mathrm{C}$ and diffusion path associated with isothermal solidification of the liquid braze alloy (phase diagram calculation based on [22])

\section{5. Solid state evolution of the brazed joint and re-melting temperature}

For a joint brazed at $795^{\circ} \mathrm{C}$ in which isothermal solidification is just completed, the reaction layer sequence at the $\mathrm{Ti}$ side is, $\mathrm{Ti} / \mathrm{Ti}_{2} \mathrm{Cu} / \mathrm{TiCu} / \mathrm{Ti}_{3} \mathrm{Cu}_{4}+\mathrm{Ag} / \mathrm{TiCu}_{4}+\mathrm{Ag}$ (Section 3. 3, Fig. 2). According to the reaction scheme given by Eremenko et al. [23] or to the partial liquidus projection drawn in Fig. 4, [12] the re-melting temperature should theoretically be $808^{\circ} \mathrm{C}$. Indeed in the $\mathrm{Ag}-\mathrm{Cu}$-Ti ternary system, that value corresponds to the temperature of the invariant transformation:

$$
\mathrm{Ag}+\mathrm{TiCu}_{4} \rightarrow \mathrm{Ti}_{2} \mathrm{Cu}_{3}+\mathrm{L}
$$

In fact, $\mathrm{Ti}_{3} \mathrm{Cu}_{4}$ will be formed in place of $\mathrm{Ti}_{2} \mathrm{Cu}_{3}[12]$ but the re-melting temperature will not be very different. Compared with the melting temperature of the $\mathrm{Ag}-\mathrm{Cu}$ braze alloy $\left(780^{\circ} \mathrm{C}\right)$, the re-melting temperature is only slightly increased (by less than $30^{\circ} \mathrm{C}$ ). Now if the joint is maintained at the brazing temperature of $795^{\circ} \mathrm{C}$ after isothermal solidification is completed, the re-melting temperature will gradually increase. Indeed, solid state chemical reactions will proceed upon annealing between the Ti base metal and the $\mathrm{Ti}_{\mathrm{x}} \mathrm{Cu}_{\mathrm{y}}$ intermetallic compounds present at the Ti surface or in the solidified $\mathrm{Ag}$ base matrix. The chemical potential gradients of opposite sign for $\mathrm{Ti}$ and $\mathrm{Cu}$ that exist between the base metal and the AlN ceramics bring the driving force for such solid state volume diffusion processes in the whole transition zone. 


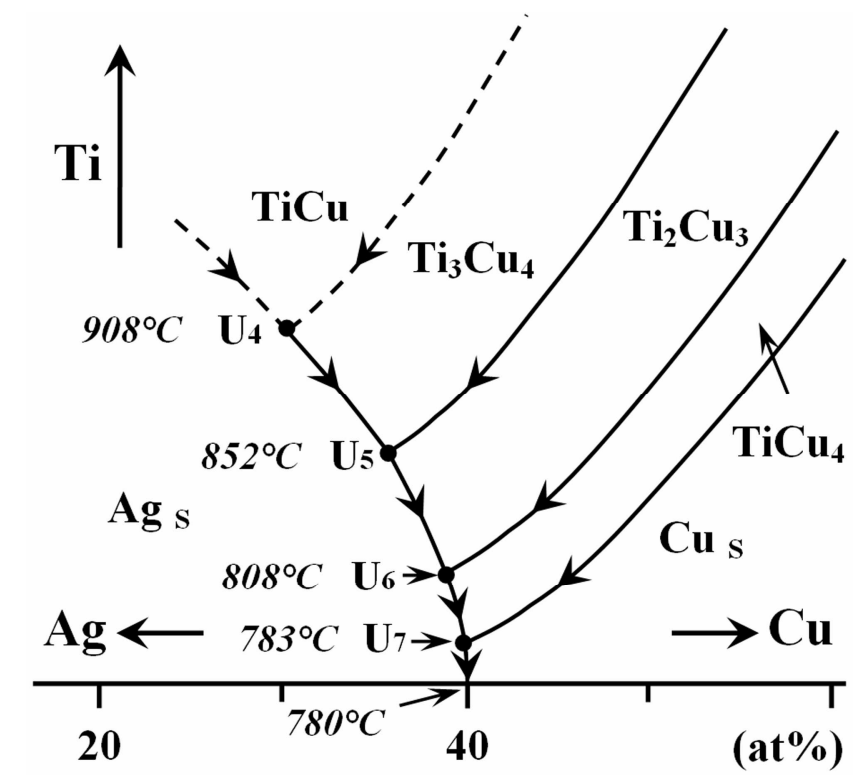

Fig. 4. Partial liquidus projection of the Ag-Cu-Ti phase diagram between 880 and $780^{\circ} \mathrm{C}$ after. $[12,23]$

Accordingly, all the $\mathrm{TiCu}_{4}$ initially formed at a high rate will be converted first into $\mathrm{Ti}_{3} \mathrm{Cu}_{4}$ and then into $\mathrm{TiCu}$ and $\mathrm{Ti}_{2} \mathrm{Cu}\left(\mathrm{Ti}_{2} \mathrm{Cu}_{3}\right.$ is missing because solid state growth only proceeds slowly [12]). Fig. 5 shows a joint that has been annealed at $798^{\circ} \mathrm{C}$ for 15 hours after having been brazed at $850^{\circ} \mathrm{C}$ for $1 \mathrm{~min}$. Only two intermetallic compounds were characterized by EPMA in the transition zone between the Ti base metal and the AlN ceramics: (i) $\mathrm{TiCu}$ with partial $\mathrm{Cu} / \mathrm{Ag}$ substitution that forms a continuous intermediate layer with a thickness of 10-15 $\mu \mathrm{m}$ and (ii) $\mathrm{Ti}_{2} \mathrm{Cu}$ that appears in the form of flakes mixed with Ti over a depth of $60 \mu \mathrm{m}$, of a single-phased inner layer and of globular crystals in contact with the Ag-rich matrix (Fig. 5). It is notable that the whole reaction layer contains a few atomic percents of $\mathrm{Al}$, which indicates that secondary reactions in relation with the vicinity of the AlN ceramics occurs after long time annealing. Neglecting Al diffusion, the remelting temperature for such a joint in which all the Ti$\mathrm{Cu}$ compounds initially formed are converted into $\mathrm{TiCu}$ and $\mathrm{Ti}_{2} \mathrm{Cu}$ upon annealing is close to that of the invariant transformation: 


$$
\mathrm{Ag}+\mathrm{TiCu} \rightarrow \mathrm{Ti}_{2} \mathrm{Cu}+\mathrm{L}
$$

For that transformation, Eremenko et al. report a temperature of $908^{\circ} \mathrm{C}$ [23]. Compared with the starting $\mathrm{Ag}-\mathrm{Cu}$ alloy that melts at $780^{\circ} \mathrm{C}$, the re-melting temperature of the braze joint after 15 hours annealing is then nearly $130^{\circ} \mathrm{C}$ higher.

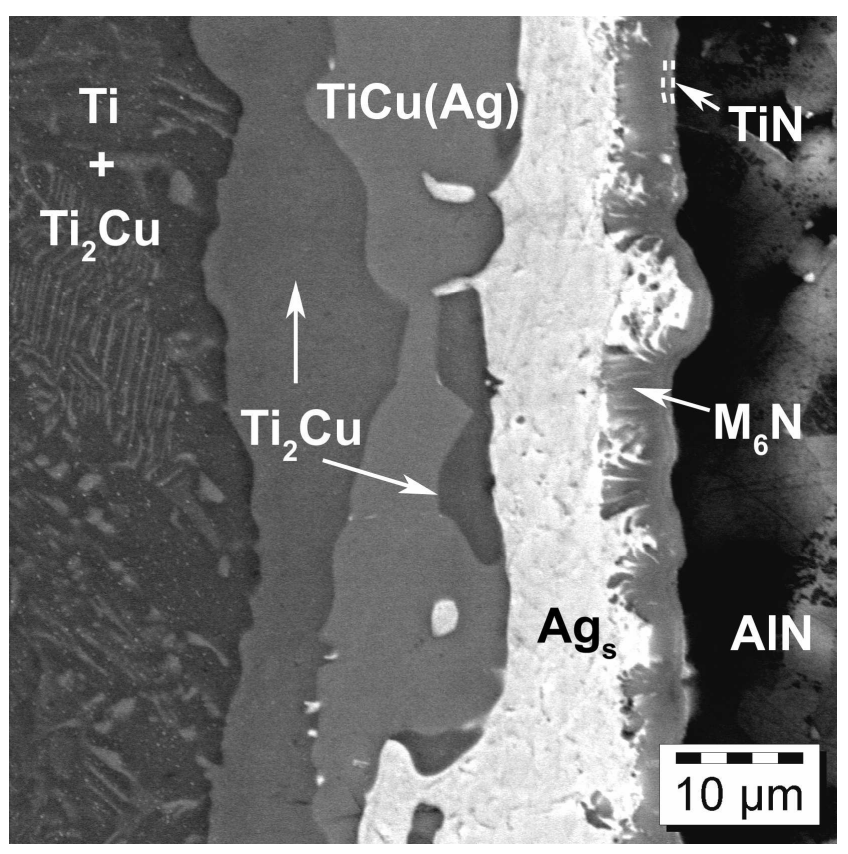

Fig. 5. SEM image of a Ti/ $\mathrm{Ag}-\mathrm{Cu} 40$ at $\% / \mathrm{AlN}$ joint after brazing for $1 \mathrm{~min}$ at $850^{\circ} \mathrm{C}$ and subsequent annealing at $798^{\circ} \mathrm{C}$ for $900 \mathrm{~min}$

\section{Conclusion}

Titanium has been successfully joined to aluminium nitride by TLPB in the temperature range $795-850^{\circ} \mathrm{C}$, using a $\mathrm{Ag}-\mathrm{Cu} \mathrm{Cusil} \circledast \mathrm{commercial}$ braze alloy. At $850^{\circ} \mathrm{C}$, the liquid alloy rapidly spreads by reactive wetting onto AlN while $\mathrm{Cu}$ contained in this alloy reacts with $\mathrm{Ti}$ to form four intermetallic compounds: $\mathrm{Ti}_{2} \mathrm{Cu}, \mathrm{TiCu}, \mathrm{Ti}_{3} \mathrm{Cu}_{4}$ and $\mathrm{Ti}_{2} \mathrm{Cu}_{3}$. As a result of that interaction, the braze alloy is impoverished in $\mathrm{Cu}$ but the majority is still in the liquid state after $8 \mathrm{~min}$ brazing. At $795^{\circ} \mathrm{C}$, reactive wetting and spreading at the AlN/ braze alloy interface occurs, whereas isothermal solidification of the braze 
alloy by chemical reaction with titanium proceeds faster than at $850^{\circ} \mathrm{C}$. This surprising fast solidification is explained by the nucleation and growth in the liquid braze alloy of the $\mathrm{Cu}$-rich compound $\mathrm{TiCu}_{4}$.

More generally, a good understanding of the physical-chemical processes that develop during bonding has been achieved on the basis of thermodynamic and kinetic considerations in the Ag-Cu-Ti ternary system. Reactive wetting at the AlN/ braze alloy interface involving $\mathrm{TiN}_{1-\mathrm{x}}$ formation has been observed to proceed only for a chemical activity of $\mathrm{Ti}$ in the liquid braze alloy higher than a threshold value, what is in agreement with thermodynamic data. Reaction layer sequences at the Ti/braze alloy interface have been related to the Ag-Cu-Ti phase diagram using the diffusion path concept. Re-melting temperatures have been evaluated from reaction scheme data. For a brazed joint just solidified at a brazing temperature of $795^{\circ} \mathrm{C}$, the re-melting temperature is $808^{\circ} \mathrm{C}$, i.e. less than $30^{\circ} \mathrm{C}$ above the melting temperature of the starting braze alloy $\left(780^{\circ} \mathrm{C}\right)$. Now for the same joint further annealed for 15 hours at $798^{\circ} \mathrm{C}$, the re-melting temperature increases to $908^{\circ} \mathrm{C}$ which is nearly $130^{\circ} \mathrm{C}$ higher than the melting point of the starting braze alloy.

Acknowledgements. The authors gratefully acknowledge the French Ministry for Research for funding this research work in the framework of the generic program "Supersonique". Many thanks are also due to the staff of Microscopy Centre from University Lyon $1(\mathrm{CT} \mu)$ where SEM observations and EPMA analyses were performed. 


\section{References}

[1] N. Eustathopoulos, M. G. Nicholas, B. Drevet, Wettability at high temperatures, Pergamon, Amsterdam, Netherlands, 1999.

[2] M. Schwartz, Brazing for the Engineering Technologist, Chapman and Hall, London, 1995.

[3] H. Y. Chan, R. K. Shiue, J. Mater. Sci. Lett. 22 (2003) 1659-1663.

[4] M. Li, C. Li, F. Wang, W. Zhang, CALPHAD 29 (2005) 269-275.

[5] Y. Iino, J. Mater. Sci. Lett. 10 (1991) 104-106.

[6] A. M. Glaeser, Transient liquid phase ceramic bonding, US Patent 5.234.152, USA, 1992.

[7] W. F. Gale, D. A. Butts, Sci. Technol. Weld. Joi. 9 (2004) 283-300.

[8] D. S. Duvall, W. A. Owczarski, D. F. Paulonis, Weld. J. 53 (1974) 203-214.

[9] J. D. M. Sugar, J.T.; Akashi, T.; Hong, S.M.; Nakashima, K. \& Glaeser, A. M., J. Eur. Ceram. Soc. 26 (2006) 363-372.

[10] G. Rosazza Prin, T. Baffie, M. Jeymond, N. Eustathopoulos, Mater. Sci. Eng. A A298 (2001) 34-43.

[11] S. Kalogeropoulou, C. Rado, N. Eustathopoulos, Scr. Mater. 41 (1999) 723-728.

[12] J. Andrieux, O. Dezellus, F. Bosselet, M. Sacerdote-Peronnet, C. Sigala, R.

Chiriac, J. C. Viala, J. Phase Equilib. Diff. accepted (2007).

[13] M. F. Wu, Z. S. Yu, C. Y. Jiang, C. Liang, Mater. Sci. Technol. 18 (2002) 13141315 .

[14] H. Y. Chan, D. W. Liaw, R. K. Shiue, Mater. Lett. 58 (2004) 1141-1146.

[15] A. P. Tomsia, R. E. Loehman, Mater. Manuf. Processes 9 (1994) 547-561.

[16] N. Y. Taranets, H. Jones, Mater. Sci. Eng. A A379 (2004) 251-257.

[17] A. H. Carim, R. E. Loehman, J. Mater. Res. 5 (1990) 1520-1529. 
[18] Q. Chen, B. Sundman, J. Phase Equilib. 19 (1998) 146-160.

[19] M. W. Chase, NIST-JANAF Thermochemical Tables, $3^{\text {rd }}$ Edition, D. R. Lide, National Bureau of Standards, 1998.

[20] F. R. De Boer, R. Boom, A. R. Miedema, Physica, B+C 101 (1980) 294-319.

[21] N. Durlu, U. Gruber, M. A. Pietzka, H. Schmidt, J. C. Schuster, Z. Metallkd. 88 (1997) 390-400.

[22] R. Arroyave, Thermodynamics and kinetics of ceramic/metal interfacial interactions, $\mathrm{PhD}$ Thesis, Departement of Materials Science and Engineering, Massachussets Institute of Technology, 2004.

[23] V. N. Eremenko, Y. I. Buyanov, N. M. Panchenko, Sov. Powder Metall. Met. Ceram. 9 (1970) 301-304. 